\title{
TRANSPORT OF BROILERS: LOAD MICROCLIMATE DURING BRAZILIAN SUMMER
}

\section{JOSÉ A. D. BARBOSA FILHO ${ }^{1}$, MARÍLIA L. V. QUEIROZ ${ }^{2}$, DANIEL DE F. BRASIL ${ }^{3}$, FREDERICO M. C. VIEIRA ${ }^{4}$, IRAN J. O. SILVA ${ }^{5}$}

\begin{abstract}
The objective of this study was to characterize the microclimatic profile of broiler transport trucks under commercial conditions, in the summer, by continuous monitoring of environmental variables (temperature and air relative humidity). Three loads were monitored from farm to slaughterhouse, considering factors such as distance and day periods (morning, afternoon, and night). To obtain the profile of the environmental variables during journey, data loggers, that determined the microclimate to which birds were submitted, were installed in the trucks; data loggers also allowed visualization of the Enthalpy Comfort Index (ECI) so that load regions could be classified according to heat comfort limits for 6-week old poultries. Temperature, relative humidity, and ECI in the truck were analyzed, using geostatistics, by the ordinary kriging method. The afternoon was the most critical period, and truck central and rear regions were most problematic for chickens, thus most susceptible to losses.
\end{abstract}

KEYWORDS: poultry farming, animal welfare, pre-slaughter operations, heat stress.

\section{TRANSPORTE DE FRANGOS: CARACTERIZAÇÃO DO MICROCLIMA DA CARGA DURANTE O VERÃO BRASILEIRO}

RESUMO: Este trabalho foi conduzido com o objetivo de caracterizar o perfil microclimático da carga de caminhões de transporte de frangos de corte sob condições comerciais, durante o verão brasileiro, por meio do monitoramento constante das variáveis meteorológicas (temperatura e umidade relativa do ar). Foram monitorados três carregamentos, da saída das aves da granja até a chegada ao abatedouro, em que se consideraram fatores como a distância e os turnos (manhã, tarde e noite). Para a obtenção do perfil das variáveis ambientais durante o transporte dos animais, foram instaladas ao longo da carga miniestações meteorológicas (Data Loggers) que permitiram determinar o microclima a que as aves foram submetidas e visualizar o perfil do Índice Entalpia de Conforto (IEC). Com estes valores, foi possível a classificação das regiões da carga de acordo com os limites de conforto térmico para frangos de corte, na sexta semana de vida. Os dados de temperatura, umidade relativa do ar e do IEC na carga foram analisados, utilizando-se da geoestatística pelo método de krigagem ordinária. O turno da tarde foi o mais crítico, com ênfase no conforto térmico das aves, sendo que as partes central e traseira da carga do caminhão foram as mais problemáticas, portanto as mais propícias à ocorrência de perdas.

PALAVRAS-CHAVE: avicultura, bem-estar animal, operações pré-abate, estresse térmico.

\footnotetext{
${ }^{1}$ Eng ${ }^{0}$ Agrícola, Prof. Adjunto, Departamento de Engenharia Agrícola, NEAMBE-UFC, Fortaleza - CE, Fone: (85) 33669128,zkdelfino@gmail.com.

${ }^{2}$ Eng ${ }^{0}$ Agrônomo, M.Sc, Departamento de Engenharia Agrícola, NEAMBE-UFC, Fortaleza - CE, marilialvqueiroz@gmail.com

${ }^{3}$ Eng ${ }^{0}$ Agrônomo, M.Sc, Departamento de Engenharia Agrícola, NEAMBE-UFC, Fortaleza - CE, danieldfb@gmail.com

${ }^{4}$ Zootecnista, Prof. Adjunto, Grupo de Estudos em Biometeorologia (GEBIOMET), UTFPR, Dois Vizinhos - PR, fredericovieira@utfpr.edu.br

${ }^{5}$ Engo Agrícola, Prof. Adjunto, Departamento de Engenharia de Biossistemas, Escola Superior de Agricultura “Luiz de Queiroz” ESALQ/USP, iranoliveira@usp.br 


\section{INTRODUCTION}

In the pre-slaughter period, formed by broiler capture, loading, transport, and lairage time at the slaughterhouse, management practices are considered harmful to chickens and may compromise their welfare, survival, and meat quality. According to ROCHA et al. (2008), 90\% of the injuries observed by the sanitary inspection service occur in that stage.

The pre-slaughter transport of poultries consists in carrying animals from farm to slaughterhouse under the most different conditions and combinations of distances and times. These combinations directly reflect on meat quality and, in most cases, are primarily responsible for losses (deaths). There is a direct association between meat quality and pre-slaughter handling either at the farm, animal transport, or slaughterhouse (SANTOS et al., 2010).

During transport, chickens are subjected to stress factors that compromise their well-being and cause damages, such as high mortality and reduced meat quality (MITCHELL et al., 1992; MITCHELL \& KETTLEWELL, 1998). SILVA et al. (2009) emphasized that one of the most recent requirements of the import market is related to animal welfare; also, that there is a need for investments in updating standards and laws on animal welfare in Brazil to maintain its international competitiveness, especially during pre-slaughter operations.

The main stress factors during broiler transport are related to the load microclimate; high values of temperature and relative humidity are the major responsible for the so-called 'dead on arrival' (HUNTER et al., 1997; MITCHELL \& KETTLEWELL, 1998). The formation of a thermal microclimate inside vehicles affects poultry welfare and potentially promotes the development of PSE meat (SIMÕES et al., 2009). OLIVEIRA \& LINDAU (2012) highlight that, besides contamination and loss of meat quality, the transport also affects the injury rates, resulting in partial rejection of affected parts. Studies conducted in Europe indicate that $40 \%$ of dead on arrival are caused by the transport to slaughterhouse (BAYLISS \& HINTON, 1990).

Distribution of dead birds in the load is not random; it rather reflects the variation of ventilation and comfort regions. KETTEWELL \& MITCHELL (1993) performed a threedimensional characterization of the environmental conditions inside chicken transport trucks, and observed great heterogeneity of the environmental variables throughout the loads.

Metabolic heat production by poultries during transport creates thermal gradients between transport crates and the outer environment, which may be entirely affected by the action of the wind, resulting, in turn, in a heterogeneous temperature distribution throughout the truck load (MITCHELL \& KETTLEWELL, 1994). Studies (MITCHELL et al., 1992; KETTLEWELL \& MITCHELL, 1993; KETTLEWELL et al., 1993) point out the presence of a thermal core in truck loads originated by poor ventilation and, also, in places where load heat and humidity are higher. However, these studies were developed in temperate regions, lacking researches that evidence the load thermal profile under tropical conditions, especially when seasonal intense daily thermal fluctuations are considered.

Given the increasing technological progress in the poultry industry, the assessment of factors that influence loss reduction is important (SILVA \& VIEIRA, 2010). Thus, this study aimed to characterize the load microclimatic profile in broiler transport trucks during summer in Brazil, and to relate this information to losses during pre-slaughter handling.

\section{MATERIAL AND METHODS}

The experiment was performed in an integrative company and slaughterhouse located in São Paulo State, Brazil, with a mean of 300 thousand birds slaughtered daily. According to data from a weather station at that location, altitude in the region is, on average, $800 \mathrm{~m}$, with a high-altitude tropical climate (Cwa - according to Köeppen classification), dry winters and hot and humid summers. In colder months, the mean temperature may remain below $18{ }^{\circ} \mathrm{C}$, and in warmer months, above $25{ }^{\circ} \mathrm{C}$, with monthly mean relative humidity varying between 53 and $89 \%$. 
The experiment lasted one month during summer. Broilers of Cobb breed were used, which aged 6-7 weeks. Three loadings were monitored, from poultry output at the farm until arrival at the slaughterhouse, considering factors such as distance and travel shifts.

Three transport shifts (morning, from 7:00 to 11:59 am; afternoon, from 12:00 to 5:59 pm; and night, from 6:00 pm to 6:59 am) and different distances from farm to slaughterhouse were evaluated.

Chicken transport was performed as follows: all monitored trucks had loadings of 486 transport crates arranged into three rows (two lateral and one central), composed of 9 boxes height and 18 boxes length.

To obtain the profile of environmental variables across the load, data loggers (Logen ${ }^{\circledR}$ ) were set up along the truck length, allowing determination of the microclimate to which birds were subjected, as well as Enthalpy Comfort Index (ECI) that, in turn, enabled the classification of load regions according to thermal comfort limits for 6-week old broilers. Enthalpy (h) is a thermal comfort index that expresses the heat amount in $1 \mathrm{~kg}$ dry air, in $\mathrm{kJ}$, determined by the equation cited by BARBOSA FILHO (2005).

$$
\mathrm{h}=\left(6.7+0.243 \mathrm{t}+\left(\left(\frac{\mathrm{RH}}{100}\right) \cdot 10^{\left.\mathrm{c}^{7.5 \mathrm{t}} / 237.3+\mathrm{t}\right)}\right)\right) 4.18
$$

where,

$$
\begin{aligned}
& \mathrm{h} \text { - enthalpy, } \mathrm{kJ} / \mathrm{kg} \text { dry air; } \\
& \mathrm{t} \text { - temperature, }{ }^{\circ} \mathrm{C} \text {, and } \\
& \mathrm{RH} \text { - relative humidity, } \% \text {. }
\end{aligned}
$$

To facilitate data logger distribution and cover the entire load length, we chose a fixed and standard configuration for all loadings (Figure 1). This configuration included 47 data loggers arranged, mainly, at the load central region, assuming that this would be the most prone to the occurrence of heat stress in birds.

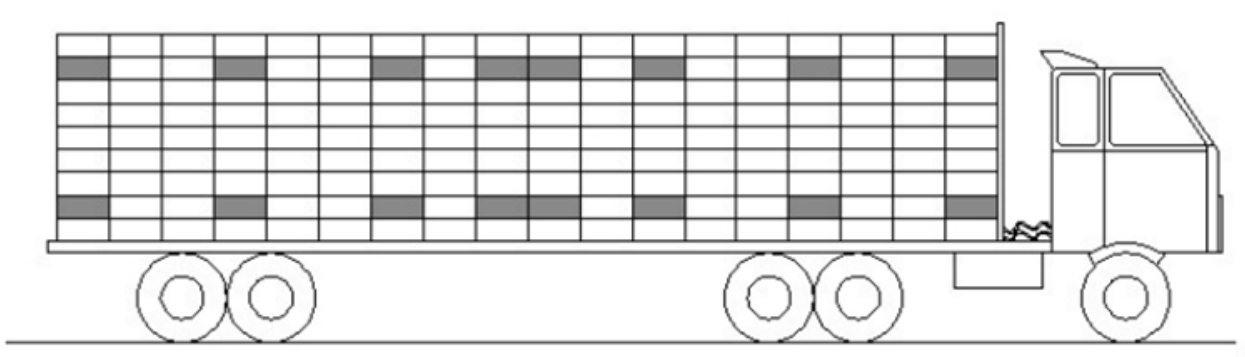

FIGURE 1. Fixed loggers (dark boxes) throughout the load.

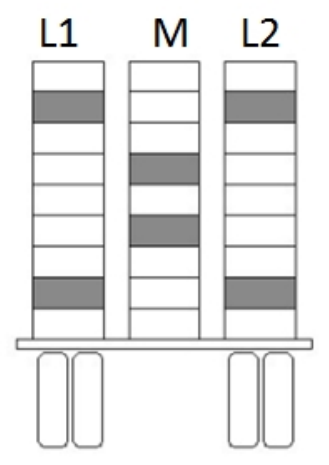

For the three evaluated loadings, profiles of temperature and relative humidity were monitored both inside and outside the truck load, as well as particular characteristics of each journey, such as traveled distance, transport shift, travel time, density of broilers per box, and percentage of dead on arrival at the slaughterhouse.

Data of temperature, relative humidity, and Enthalpy Comfort Index (ECI) across the load were analyzed using geostatistics (ordinary kriging) to obtain the other load points, and to evaluate the spatial dependence of the environmental variables, considering the interior of the truck load as the study area. For each data set, samples were divided into three groups: L1 - lateral 1; M - middle; and L2 - Lateral 2.

The free software R (R DEVELOPMENT CORE TEAM, 2006) was used for all analyses. 


\section{RESULTS AND DISCUSSION}

The mean distance traveled from farm to slaughterhouse is presented in Table 1. Travel times followed the same distance variations, since longer times were observed during the morning and night.

TABLE 1. Means of external environmental variables for each transport shift of birds.

\begin{tabular}{|c|c|c|c|c|c|c|c|}
\hline Season & Shift & Distance $(\mathrm{km})$ & Time & Poultry/box & $\begin{array}{c}\text { Temperature } \\
\left({ }^{\circ} \mathrm{C}\right)\end{array}$ & $\begin{array}{c}\text { Relative } \\
\text { humidity (\%) }\end{array}$ & \%Death \\
\hline \multirow{3}{*}{ Summer } & Morning & 63 & $1 \mathrm{~h} 20 \mathrm{~min}$ & 7 & 25.1 & 68 & 0.24 \\
\hline & Afternoon & 31 & $52 \min$ & 7 & 29.1 & 70 & 0.42 \\
\hline & Night & 51 & $1 \mathrm{~h} 23 \mathrm{~min}$ & 7 & 25.9 & 75 & 0.33 \\
\hline
\end{tabular}

According to Table 1, it was possible to observe a great percentage increase of dead birds, reaching nearly $0.50 \%$, in comparison with the results found by BARBOSA FILHO (2008). This reflects the risks and, also, the special attention that must be paid during pre-slaughter handling in this season, especially regarding transport (TABBAA \& ALSHAWABKEH, 2000; WARRISS et al., 2005; PETRACCI et al., 2006; VECEREK et al., 2006).

Percentages of dead on arrival, listed in Table 1 , are close to $0.47 \%, 0.34 \%$, and $0.45 \%$ reported by, respectively, PETRACCI et al. (2006), BAYLISS \& HINTON (1990), and WARRIS et al. (2005), also during summer.

External environmental conditions followed the regular oscillations of summer day shifts in the experimental region. The mean temperature was $26.7^{\circ} \mathrm{C}$ and, relative humidity, $71 \%$.

The percentage of dead on arrival (\%Death) initially indicates the expected, that is, greater losses in the afternoon, period with higher evidence of thermal stress (WARRISS et al., 2005). These values of temperature, according to MACARI \& FURLAN (2001), exceed the limits of thermal comfort for 6-week old broilers, and are related to higher values of death percentage (Table 1).

TABLE 2. Means of environmental variables across the load for each transport shift of birds.

\begin{tabular}{ccccccc}
\hline \multirow{2}{*}{ Season } & Shift & $\begin{array}{c}\text { Temperature } \\
\left({ }^{\circ} \mathrm{C}\right)\end{array}$ & $\begin{array}{c}\text { Relative Humidity } \\
(\%)\end{array}$ & $\begin{array}{c}\text { ECI (kJ/kg } \\
\text { dry air) }\end{array}$ & \% Death & Wetting \\
\hline \multirow{3}{*}{ Summer } & Morning & 25.7 & 51 & 52.2 & 0.24 & No \\
& Afternoon & 28.4 & 73 & 72.8 & 0.42 & Yes \\
& Night & 26.0 & 74 & 65.1 & 0.33 & Yes \\
\hline
\end{tabular}

Overall means of the environmental variables, from three transported loadings monitored in the summer (Table 2), were obtained by 47 data loggers distributed throughout the load profile, resulting in a single value of the load environmental conditions during transport, which may be used as a standard comparison among shifts.

Considering the load heat (load ECI) in the trucks during transport (Table 2), and according to the classification of the Practical Tables on Enthalpy (BARBOSA FILHO et al., 2007), the morning period is the most indicated for broiler transport. Therefore, the Enthalpy Comfort Index classification for afternoons and nights indicates that these periods require more attention regarding problems with thermal stress.

Furthermore, it is important to analyze the efficiency of the wetting practice on the load heat decrease. Values of relative humidity across the load changed according to wetting, ranging from around $50 \%$ to higher than $70 \%$ (Table 2). There is a remarkable difference among values of load heat (load ECI) obtained in the afternoon, when wetting is performed, and those collected in the 
morning. SIMÕES et al. (2009), who studied broiler transport during the Brazilian summer, found lower temperature and higher relative humidity values when bird wetting was carried out. This trend was observed for both short and medium distances between farms and slaughterhouses.

It is worth mentioning that very high values of relative humidity may severely affect the heat exchange system of birds, thus compromising thermal comfort and welfare. This occurs because the best way for heat dissipation used by birds is hyperventilation (increased respiratory rate), and such exchange is impaired by high values of relative humidity (BROSSI et al., 2009). This happens, mainly, during Brazilian summer, which is characterized by a period of high temperature and relative humidity that may result in an acute heat stress, once wetting is frequently performed without criteria and may neutralize latent heat losses by air saturation in the load microclimate.

In an experiment on broiler transport in the summer, LANGER et al. (2010) registered that bird wetting in long distance journeys helped to improve the load microclimate, and reduced the occurrence of birds with PSE meat, from 52 to 44\%, in comparison with non-wetted birds. For short distances, the greater occurrence of PSE meat was found in the lot of wetted broilers; probably, according to these authors, shorter distance conditions do not provide sufficient time for animal cooling by ventilation.

There was a lower variation in the temperature values for morning and afternoon shifts (Table 3 ), in comparison with the night, what may characterize a change due to either presence or absence of load wetting.

TABLE 3. Ranges of environmental variables (temperature and humidity) and Enthalpy Comfort Index (ECI) for each part of the load (L1, M, and L2) during transport shifts.

\begin{tabular}{|c|c|c|c|c|c|c|}
\hline \multirow[b]{2}{*}{ Season } & \multirow[b]{2}{*}{ Shift } & \multirow[b]{2}{*}{ Wetting } & \multicolumn{3}{|c|}{ Amplitude } & \multirow[b]{2}{*}{ Variable } \\
\hline & & & L1 & $\mathrm{M}$ & L2 & \\
\hline \multirow{9}{*}{ Summer } & Morning & No & 5.2 & 3.5 & 2.7 & \\
\hline & Afternoon & No & 4 & $\ldots .$. & 4.6 & Temperature \\
\hline & Night & Yes & 7 & 7 & 2.8 & \\
\hline & Morning & No & 11.5 & $\ldots$. & 11.5 & \\
\hline & Afternoon & No & 6.5 & 12 & $\ldots$ & Relative Humidity \\
\hline & Night & Yes & 35 & 25 & $\ldots$. & \\
\hline & Morning & No & 8.5 & 5 & 4 & \\
\hline & Afternoon & No & $\ldots .$. & $\ldots$. & 9.5 & ECI \\
\hline & Night & Yes & 12 & 9.5 & 9.5 & \\
\hline
\end{tabular}

Considering the amplitude of relative humidity values, there was again a strong influence of load wetting on changing these values. A great variation in the humidity amplitude at night is observed, in comparison with morning and afternoon, due to the high relative humidity associated with load wetting.

For the Enthalpy Comfort Index (ECI), as observed for humidity, there was a great difference among morning and afternoon periods, and night, although it was not possible to verify the afternoon values. This difference indicates that load wetting before transport during the night may cause problems due to possible high relative humidity, hindering thermal exchanges of broilers and turning the microclimate inappropriate for broiler transport.

Importantly, there was a small difference of ECI values among the evaluated shifts (Figure 2). The ECI profile for the afternoon is not presented because of lack of spatial dependence among sampled points, observed during data geostatistical analysis. In the morning, a wide range of thermal comfort across the load profile was observed; it is the best period for chicken transport, because it provides more favorable environmental conditions for pre-slaughter handling. 

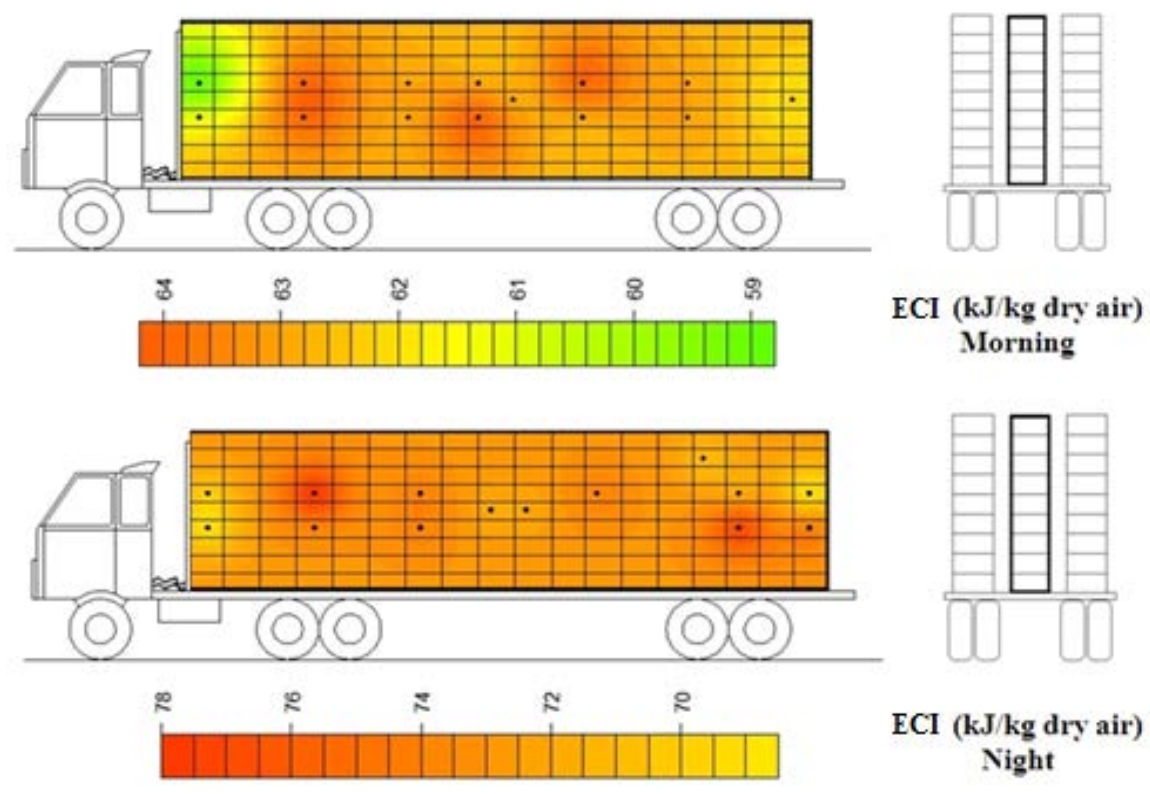

FIGURE 2. Profile of the Enthalpy Comfort Index (ECI) throughout the load middle row for the evaluated shifts (Morning and Night).

The night shift presented an inadequate profile of thermal comfort for 6-week old broilers, which varied from 54.7 to $62.9 \mathrm{~kJ} / \mathrm{kg}$ dry air (BARBOSA FILHO et al., 2007). In this shift, variation in the Enthalpy Comfort Index is probably similar to the afternoon, with high values, enabling the classification of almost all load regions into alert situation regarding thermal comfort conditions for 6-week old birds. The reason for the profile similarity between night and afternoon shifts is the influence of load wetting. This procedure certainly contributed to elevate the values of relative humidity throughout the load in these periods, which, in turn, changed ECI values.

Load rear and central regions presented the worst microclimatic conditions for chickens in the morning period; for the afternoon, load front and back regions were inadequate; and for the night, the worst areas for broiler loads were the front and central regions (Table 4). LANGER et al. (2010) found heterogeneous values of wind speed during bird transport, and higher temperatures at the vehicle rear; furthermore, chickens located at the rear region produced larger amounts of PSE meat.

TABLE 4. Regions of worst microclimate along the load shift regarding bird transport.

\begin{tabular}{cccccc}
\hline \multirow{2}{*}{ Season } & & & \multicolumn{2}{c}{ Region of worst microclimate } \\
\cline { 4 - 6 } & Shift & Wetting & L1 & M & L2 \\
\multirow{3}{*}{ Summer } & Morning & No & Central & Central & Rear \\
& Afternoon & Yes & Front & $\ldots . .$. & Rear \\
& Night & Yes & Front & Central & Central \\
\hline
\end{tabular}

During summer, all periods presented a high rate of losses; however, the afternoon represented the most damaging period, causing losses during pre-slaughter handling of poultries. Therefore, it is recommended to avoid animal transporting during periods of higher temperatures. Most broilers dead on arrival were located, mainly, in the load central region, which had more inappropriate microclimatic conditions for thermal comfort of poultries (HUNTER et al., 1997).

Regarding the variation in the load microclimate during transport, for the three studied shifts (morning, afternoon, and night) during Brazilian summer, it was possible to observe certain similarity to this same pre-slaughter handling performed in the winter, as reported by BARBOSA FILHO et al. (2009); the afternoon is also highlighted as the most susceptible period to losses caused by thermal stress. 
In this way, it is necessary to observe that broiler transport in Brazil, in both summer and winter, during the afternoon shift, may result in higher loss rates. Moreover, for both seasons, critical points, such as bird density per crate and travel time, should also be considered.

\section{CONCLUSIONS}

For pre-slaughter transport of broilers under the environmental conditions of the Brazilian summer, the morning period is the most indicated for this operation, while afternoon and night shifts are the most susceptible to losses caused by thermal stress.

\section{REFERENCES}

BARBOSA FILHO, J.A.D. Avaliação do bem-estar de aves poedeiras em diferentes sistemas de produção e condições ambientais utilizando análises de imagens. 2005. 123 f. Dissertação (Mestrado em Física do Ambiente Agrícola) - Escola Superior de Agricultura "Luiz de Queiroz”, Universidade de São Paulo, Piracicaba, 2005.

BARBOSA FILHO, J.A.D.; VIEIRA, F.M.C.; GARCIA, D.B. et al. Mudanças e uso das tabelas de entalpia. Piracicaba, 2007. Disponível em: <http://www.nupea.esalq.usp.br/tabelas-deentalpia/frangos-de-corte>. Acesso em: 03/01/2014.

BARBOSA FILHO, J. A. D. Caracterização quantiqualitativa das condições bioclimáticas e produtivas nas operações pré-abate de frangos de corte. 2008. $174 \mathrm{f}$. Tese (Doutorado em Física do Ambiente Agrícola) - Escola Superior de Agricultura "Luiz de Queiroz", Universidade de São Paulo, Piracicaba, 2008.

BARBOSA FILHO, J. A. D.; VIEIRA, F. M. C.; SILVA, I. J. O.; GARCIA, D. B.; SILVA, M. A. N.; FONSECA, B. H. F. Transporte de frangos: caracterização do microclima na carga durante o inverno. Revista Brasileira de Zootecnia, Viçosa - MG, v.38, p.2442-2446, 2009.

BAYLISS, P. A.; HINTON, M. H. Transportation of broilers with special reference to mortality rates. Applied Animal Behaviour Science, Amsterdam, v.28, p.93-118, 1990.

BROSSI, C.; CONTRERAS-CASTILLO, C. J.; AMAZONAS, E. A.; MENTEN, J. F. M. Estresse térmico durante o pré-abate em frangos de corte. Ciência Rural, Santa Maria, v.39, n.4, p.12961305, 2009.

HUNTER, R. R.; MITCHELL, M. A.; MATHEU, C. Distribution of "Dead on Arrivals" within the bio-load on commercial broiler transporters: correlation with climatic conditions and ventilation regimen. British Poultry Science, London v.38, p.7-9, 1997.

KETTLEWELL, P. J.; MITCHELL, M. A. The thermal environment on poultry transport vehicles. In: INTERNATIONAL SYMPOSIUM, 4., 1993, St. Joseph. Proceedings... St. Joseph: American Society of Agricultural Engineers, 1993. p.345-389.

KETTLEWELL, P. J.; MITCHELL, M. A.; MEEHAN, A. The distribution of thermal loads within poultry transport vehicles. Agricultural Engineer, Bedford, v.48, p.26-30, 1993.

LANGER, R. O. S.; SIMÕES, G. S.; SOARES, A. L.; OBA, A.; ROSSA, A.; SHIMOKOMAKI, M.; IDA, E. I. Transportation conditions in a brazilian commercial line and the occurrence of breast pse (pale, soft, exudative) meat and dfd-like (dark, firm, dry) meat. Brazilian Archives of Biology and Technology, Curitiba, v.53, n.5, p.1161-1167, 2010.

MACARI, M.; FURLAN, R. L. Ambiência na produção de aves em clima tropical. In: SILVA, I. J. O. (Ed.). Ambiência na produção de aves em clima tropical. Piracicaba: FUNEP, 2001. v.1, p.3187.

MITCHELL, M. A.; KETTLEWELL, P. J. Physiological stress and welfare of broiler chickens in transit: solutions not problems! Poultry Science, Champaign, v.77, p.1803-1814, 1998. 
MITCHELL, M. A.; KETTLEWELL, P. J. Road transportation of broiler-chickens - induction of physiological stress. World's Poultry Science Journal, Ithaca, v.50, p.57-59, 1994.

MITCHELL, M. A.; KETTLEWELL, P. J.; MAXWELL M. H. Indicators of physiological stress in broiler chickens during road transportation. Animal Welfare, Washington, v.1, p.91-103, 1992.

OLIVEIRA, G. A.; LINDAU, L. A. A framework for delivery scheduling in the poultry industry. Journal of Scheduling, v.15, p.757-772, 2012.

PETRACCI, M.; BIANCHI, C. C.; GASPARI, P.; LAVAZZA, A. Preslaughter mortality in broiler chickens, turkeys and spent hens under commercial slaughtering. Poultry Science, Champaing, v.85, p. 1660-1664, 2006.

R DEVELOPMENT CORE TEAM. $R$ : a language and environment for statistical computing. Vienna: R Foundation for Statistical Computing, 2006. CD-ROM.

ROCHA, J. S. R.; LARA, L. J. C.; BAIÃO, N. C. Produção e bem-estar animal: Aspectos éticos e técnicos da produção intensiva de aves. Ciência Veterinária nos Trópicos, Recife, v.11, n.1, p.4955, 2008.

SANTOS, A. C. R.; PEREIRA, L. A.; GONÇALVES, C. A. A. Investigação de fatores que afetam a qualidade e o rendimento de carcaças de frango. Norte Científico, Boa Vista, v.5, n.1, 2010.

SILVA, I. J. O.; VIEIRA, F. M. C. Ambiência animal e as perdas produtivas no manejo pré-abate: o caso da avicultura de corte brasileira. Archivos de Zootecnia, Cordoba, v.59, p.113-131, 2010.

SILVA, R. B. T. R.; NÄÄS, I. A.; MOURA, D. J. Broiler and swine production: animal welfare legislation scenario. Scientia Agricola, Piracicaba, v.66, n.6, p.713-720, 2009.

SIMÕES, G. S.; OBA, A.; MATSUO, T.; ROSSA, A.; SHIMOKOMAKI, M.; IDA, E. I. Vehicle thermal microclimate evaluation during brazilian summer broiler transport and the occurrence of pse (pale, soft, exudative) meat. Brazilian Archives of Biology and Technology, Curitiba, v.52, p.195-204, 2009.

TABBAA, M. J.; ALSHAWABKEH, K. Some factors affecting preslaughtering mortality and damage to broilers and interaction during transportation to processing plants. Agricultural Science, Washington, v.27, p.375-384, 2000.

VECEREK, V.; GRBALOVA, S.; VOSLAROVA, E.; JANACKOVA, B.; MALENA, M. Effects of travel distance end the season of the year on death rates of broilers transported to poultry processing plants. Poultry Science, Stanford, v.85, p.1881-1884, 2006.

WARRISS, P. D.; PAGAZAURTUNDA, A.; BROWN, S. N. Relationship between maximum daily temperature and mortatily of broiler chickens during transport e lairage. British Poultry Science, London, v.46, p.647-651, 2005. 